\title{
Quality of unprocessed cooled fresh coconut water manually extracted by street vendors
}

\author{
Qualidade de águas de coco não pasteurizadas, in natura, \\ resfriadas, extraídas artesanalmente por ambulantes
}

\author{
Karoline Soares ${ }^{\text {* }}$, Daniela Morais', Vilson Góis', Jean Silva', Antônio Costa', Luana Silva'

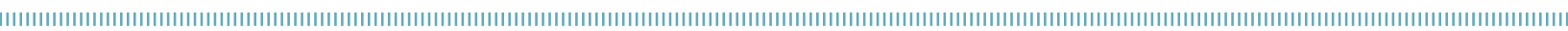

\begin{abstract}
Coconut water is a versatile beverage that is rich in nutrients, has few calories, and presents functional and therapeutic characteristics, improving the well-being and health of consumers. However, the growth of deteriorating microorganisms is facilitated by its water activity and high nutrient content; and when combined with improper handling, this product may become a carrier of foodborne diseases. Therefore, the objective of this work was to evaluate the quality of unprocessed cooled fresh coconut water manually extracted by street vendors. Twelve samples of coconut water were collected and subjected to physicochemical (total titratable acidity, $\mathrm{pH}$, and total soluble solids) and microbiological (mesophilic, and psychrotrophic microorganisms, molds, yeasts, and thermotolerant and total coliforms) analyses. The physicochemical analysis showed variations of 4.3-5.4 for $\mathrm{pH}, 0.01-0.03$ for total titratable acidity, and 2.8-6.3 for total soluble solids. The microbiological analysis showed high contamination in the samples by deteriorating microorganisms, with $58 \%$ of the samples contaminated with pathogenic microorganisms. Therefore, regular use of good hygiene practices for handling manually extracted coconut water is necessary to physicochemically and microbiologically standardize this product. Thus, ensuring the quality of the coconut water when it is manually extracted by street vendors and trade as an unprocessed, cooled, and fresh beverage and consequently minimize consumer's health risks.
\end{abstract}

KEYWORDS: microbiological analysis; food safety; consumer health risks.
RESUMO: A água de coco é uma bebida bastante versátil, pois, além de apresentar grande riqueza nutricional e poucas calorias, tem características funcionais e terapêuticas, auxiliando no bem-estar e na saúde de seus consumidores. Porém, devido a sua atividade de água e nutrientes elevados, o crescimento de micro-organismos deteriorantes é facilitado e, com a manipulaçáo inadequada do produto, a água de coco pode se tornar um veículo de doenças transmitidas por alimentos. Portanto, o presente trabalho objetivou avaliar a qualidade das águas de coco náo pasteurizadas, in natura, resfriadas, extraídas artesanalmente por ambulantes. Para tanto, coletaram-se 12 amostras distintas de água de coco, as quais foram submetidas às análises físico-química (acidez total titulável, $\mathrm{pH}$ e sólidos solúveis) e microbiológica (micro-organismos mesófilos, psicrotróficos, bolores e leveduras, coliformes totais e termotolerantes). As análises físico-químicas demonstraram variaçóes de 4,3-5,4 para o $\mathrm{pH}$ das amostras, de 0,01-0,03 para a acidez total titulável e de 2,8-6,3 para os sólidos solúveis totais. Quanto ao perfil microbiológico, verificou-se elevada contaminação por micro-organismos deteriorantes e $58 \%$ das amostras estavam contaminadas com micro-organismos patogênicos. Portanto, sugere-se aplicação regular de boas práticas de higiene e manipulação da água de coco artesanal para uma melhor padronização físico-química e microbiológica desse produto. Desse modo, garantindo melhor qualidade a essa bebida quando comercializada na forma não pasteurizada, in natura, resfriada, extraída artesanalmente por ambulantes e, consequentemente, minimizando os riscos à saúde de seus consumidores.

PALAVRAS-CHAVE: análise microbiológica; segurança alimentar; riscos à saúde do consumidor. 


\section{INTRODUCTION}

The increasing search for healthier and more nutritious foods improved the demand for coconut water in recent years, because this beverage is rich in vitamins, minerals, proteins, electrolytes, inorganic salts, has low-caloric value (ARAGÃO et al., 2001 ) and pleasant taste and aroma (LIMA et al., 2015). This drink has functional and therapeutic characteristics that benefit human health, aid in gastrointestinal processes and in functions related to the cardiovascular system (CESÁRIO et al., 2009).

Coconut water can be offered to consumers as a whole fruit containing the fresh beverage, or in alternative containers. These containers emerged as a solution to problems related mainly to volume and weight. In these cases, the coconut water can be extracted from the fruit manually or mechanically (SILVA et al., 2017).

Coconut water is commonly traded in urban centers by street vendors, who manually handle the fruits to sell this beverage. The analysis of the microbiological profile and other qualitative characteristics of the manually extracted coconut water is very important (HOFFMANN et al., 2002, MICHELIN et al., 2014), since street vendors are often informal - not legally regulated - and untrained for the work they develop (FORTUNA; FORTUNA, 2008). Moreover, scientific studies have reported the low quality of coconut water trade by street vendors, which justifies the concerns about the quality of this beverage (HOFFMANN et al., 2002, ALBUQUERQUE et al., 2011; SANTOS et al., 2013).

After extracted from the fruit, the quality of the coconut water may undergo changes that can vary depending on the form and time of storage, and handling practices (COSTA et al., 2005). Poor food hygiene practices by the handler, sanitary conditions of the establishment and utensils used to extract the beverage, and the conditions of the container used to store and sell the coconut water to the consumer may contribute to its contamination by microorganisms (MICHELIN et al., 2014). Consequently, the consumption of this food may be a risk to public health, since some pathogenic and deteriorating microorganisms, such as mesophilic, and psychrotrophic microorganisms, molds, yeasts, and coliforms can use nutrients of the coconut water to develop and directly affect this product quality (JAY, 2005; VALVERDE; BADARÓ, 2009; FORSYTHE, 2013).

Microbial proliferation and lack of sanitary standards for these fruits may compromise various aspects of the coconut water quality, including its physicochemical properties. Therefore, the quality characterization of this beverage is essential regarding its microbiological and physicochemical parameters - $\mathrm{pH}$, titratable acidity and soluble solid contents (COELHO et al., 2010; AROUCHA et al., 2014).

Hence, the objective of this paper was to evaluate the quality of unprocessed cooled fresh coconut water manually extracted by street vendors.

\section{MATERIAL AND METHODS}

Twelve samples of fresh coconut water manually extracted by street vendors in downtown Mossoró, state of Rio Grande do Norte, Brazil, were collected for evaluation. The selling locations were chosen randomly and the collection was performed in the morning, between 8 and 10 a.m.

The samples collected were stored in disposable cups provided by street vendors to represent their actual conditions, and then wrapped in aluminum foil and placed inside an isothermal box containing ice cubes produced with distilled water. The utensils used to support the sample collection were previously sterilized through application of ultraviolet radiation, thus reducing potential contaminations by the external environment.

The samples were immediately taken to the Food Biotechnology Laboratory of the Universidade Federal Rural do Semi-Árido (UFERSA), and subjected to physicochemical (total titratable acidity, $\mathrm{pH}$, and soluble solids) and microbiological (mesophilic, and psychrotrophic microorganisms, molds, yeasts, and thermotolerant and total coliforms) analyses.

Titratable acidity was determined by titration with sodium hydroxide and expressed as $\mathrm{g}$ of malic acid per $100 \mathrm{~mL}$ of the sample. The $\mathrm{pH}$ of the samples was determined using a previously calibrated portable digital potentiometer; and the total soluble solids were determined using a refractometer, with results expressed in ${ }^{\circ}$ Brix. Physicochemical analyses were performed with three replicates per sample, and the results were expressed in means, following the methodology proposed by INSTITUTO ADOLFO LUTZ (2008).

The microbiological parameters were evaluated aseptically in a laminar flow chamber, following the recommendations of SILVA et al. (2007) and APHA et al. (1998). The count of aerobic mesophilic microorganisms, aerobic psychrotrophic microorganisms, molds, and yeasts was conducted in duplicate, through conventional agar plating using the pour-plate technique.

A $25-\mathrm{mL}$ aliquot of each one of the 12 samples was taken with a previously sterilized glass pipette and diluted in $225 \mathrm{~mL}$ of peptone water to obtain a $10^{-1}$ dilution. Subsequently, $1 \mathrm{~mL}$ of each diluted sample were inoculated into sterile petri dishes, and approximately $20 \mathrm{~mL}$ of standard agar medium were added. The petri dishes were stored in a bacteriological oven at $36 \pm 1^{\circ} \mathrm{C}$ during 48 hours for the growth of mesophilic microorganisms, and at $7 \pm 1^{\circ} \mathrm{C}$ during seven days for the growth of psychrotrophic microorganisms. The counts of the colonies were performed using a colony counter.

Molds and yeasts were evaluated by taken $1-\mathrm{mL}$ aliquots of the same 12 dilutions and inoculated into sterile petri dishes, followed by the addition of approximately $20 \mathrm{~mL}$ of Potato Dextrose Agar with tartaric acid. The petri dishes were incubated upside down in a biochemical oxygen demand (BOD) incubator at $28^{\circ} \mathrm{C}$ for five days, and then the colonies were counted using a colony counter. 
The most probable number (MPN) technique was used to quantify the thermotolerant and total coliforms. Dilutions $\left(10^{-1}\right.$ to $\left.10^{-3}\right)$ were evaluated using three test tubes for each step of the methodology. The tubes were tested for total coliforms by inoculating the sample in a lauryl tryptose broth. The tubes were kept in a water bath at a controlled temperature of $35 \pm 0.5^{\circ} \mathrm{C}$ for 48 hours. The positive tubes - gas formation - were then subsampled with a platinum loop in a bright green broth to confirm the growth of total coliforms. Positive samples for total coliforms were subsampled in an Escherichia coli broth at $45 \pm 0.5^{\circ} \mathrm{C}$ for 48 hours in water bath for verifying the growth of thermotolerant coliforms.

\section{RESULTS AND DISCUSSION}

The means of physicochemical and microbiological parameters of the unprocessed cooled fresh coconut water manually extracted by street vendors are shown in Table 1 .

The total titratable acidity ranged from 0.01 to 0.03 (g per $100 \mathrm{~mL}$ ). However, the $\mathrm{pH}$ ranged from 4.3 to 4.9 in $83.3 \%$ of the samples, and from 5.2 to 5.4 in $16.6 \%$ of the samples. The acidity variation was probably due to the lack of standardization of the coconut fruits at harvesting regarding their maturity. Thus, street vendors trade fruits from early or late harvesting - inadequate maturation stage (AROUCHA et al., 2014). TAN et al. (2014) found coconut water with varying $\mathrm{pH}$ as a function of maturation stages of the fruits. CARVALHO et al. (2006) found 0.05\% variations in fruits grown for five months, and of $0.01 \%$ in fruits grown for 12 months.
LIMA et al. (2015) evaluated processed coconut water and encountered acidity above 0.03 (g per $100 \mathrm{~mL}$ ) in all samples. This result is probably because of the addition of citric acid to correct the acidity, which is allowed by the Brazilian legislation in processed coconut water.

The samples had total soluble solids (TSS) varying from 5.2 to 6.3 , with the exception of sample 11 that had a significantly lower TSS compared to the others. According to CARVALHO et al. (2006), soluble solid contents in coconut water decrease continuously from the sixth $(8.9 \%)$ to the $12^{\text {th }}$ (3.1\%) month of growth. Therefore, the variations from the present paper were probably due to the lack of standardization of fruits at harvesting.

According to the microbiological analysis, all samples showed mesophilic microorganism concentration varying from 5.13 to $6.16 \log _{10}$ colony forming unit (CFU) $\mathrm{mL}^{-1}$ (Table 1 ). SILVA et al. (2009), VALVERDE; BADARÓ (2009) also found high counts of mesophilic microorganisms in coconut water. FORTUNA; FORTUNA (2008) evaluated coconut water from street vendors in Teixeira de Freitas, Bahia, Brazil, and found growth of mesophilic microorganisms in $78 \%$ of the samples.

Presence of psychrotrophic microorganisms were found in $91.67 \%$ of the coconut water sampled, which had counts varying from 3.3 to $4.86 \log _{10} \mathrm{CFU} \mathrm{mL}^{-1}$ (Table 1). LIMA et al. (2014) also discovered high contamination by psychrotrophic microorganisms in coconut water, with counts of up to $5.39 \log _{10} \mathrm{CFU} \mathrm{mL} \mathrm{mL}^{-1}$.

The mold and yeast counts ranged from 4.43 to $6.48 \log _{10}$ CFU mL ${ }^{-1}$. This is a worrying result from the public health point of view, since fungi are deteriorating microorganisms, and some of them produce toxic substances - mycotoxins - that

Table 1. Means of physicochemical parameters and counts of microorganisms $\left(\log _{10}\right)$ in unprocessed cooled fresh coconut water manually extracted by street vendors.

\begin{tabular}{|c|c|c|c|c|c|c|}
\hline Samples & $\begin{array}{c}\text { TTA } \\
\text { (g per } 100 \mathrm{~mL} \text { ) }\end{array}$ & TSS ( ${ }^{\circ}$ Brix) & $\mathrm{pH}$ & $\begin{array}{l}\text { Psychrotrophic } \\
\text { microorganisms } \\
\left(\log _{10} \text { CFU mL } L^{-1}\right)\end{array}$ & $\begin{array}{c}\text { Mesophilic } \\
\text { microorganisms } \\
\left(\log _{10} \text { CFU mL-1) }\right.\end{array}$ & $\begin{array}{l}\text { Molds and yeasts } \\
\left(\log _{10} \mathrm{CFU} \mathrm{mL}^{-1}\right)\end{array}$ \\
\hline 1 & 0.03 & 6.0 & 4.4 & 4.65 & 5.63 & 4.43 \\
\hline 2 & 0.03 & 6.1 & 4.8 & 4.46 & 5.17 & 4.51 \\
\hline 3 & 0.03 & 5.8 & 4.9 & 4.72 & 5.21 & 5.48 \\
\hline 4 & 0.02 & 5.2 & 4.3 & 0.00 & 5.90 & 6.33 \\
\hline 5 & 0.03 & 5.9 & 4.5 & 3.60 & 6.00 & 6.25 \\
\hline 6 & 0.02 & 6.3 & 4.7 & 4.34 & 5.61 & 6.06 \\
\hline 7 & 0.02 & 6.0 & 4.9 & 4.23 & 5.98 & 6.00 \\
\hline 8 & 0.02 & 6.3 & 5.4 & 3.30 & 5.90 & 6.17 \\
\hline 9 & 0.03 & 5.4 & 4.6 & 4.08 & 5.13 & 5.45 \\
\hline 10 & 0.02 & 5.9 & 4.7 & 4.76 & 6.16 & 6.48 \\
\hline 11 & 0.01 & 2.8 & 5.2 & 4.86 & 5.71 & 6.27 \\
\hline 12 & 0.02 & 6.2 & 4.8 & 3.48 & 5.72 & 5.99 \\
\hline
\end{tabular}

TTA: total titratable acidity; TSS: total soluble solids. 
may cause toxicity, with carcinogenic potential (FREIRE et al., 2007; FORSYTHE, 2013).

Similarly, LIMA et al. (2014) encountered mold and yeast counts varying from 2.70 to $5.88 \log _{10} \mathrm{CFU} \mathrm{mL} \mathrm{m}^{-1}$ in coconut waters. In addition, SILVA et al. (2009) evaluated coconut waters in Currais Novos, Rio Grande do Norte, Brazil, and found high counts of molds and yeasts in most of the samples. However, COSTA et al. (2005) reported different results from those found in the present study, with mold and yeast counts lower than $1 \log _{10} \mathrm{CFU} \mathrm{mL} \mathrm{m}^{-1}$ in coconut water subjected to different conservation methods.

High microbial counts from the present study are probably due to the use of inadequate hygienic practices when handling and selling processes for this product by street vendors. According to VERGARA (2016), the final quality of a food depends on several factors regarding its production, such as handling and selling conditions. Coconut water is a sterile medium when it is inside the coconut; however, after its extraction, it is subjected to contamination by deteriorating microorganisms, including fungi and bacteria, since it is rich in nutrients, has low acidity, and high-water activity (JAY, 2005, VALVERDE; BADARÓ, 2009). Several factors may result in contamination of this product, such as poor food hygiene practices by the street vendors and sanitary conditions of the utensils used to extract the beverage and containers used to store and sell the product to the consumer (MICHELIN et al., 2014).

Foods can be contaminated when manually handled without the adequate hygiene practices recommended by the Brazilian National Sanitary Surveillance Agency (ANVISA) in decree 326/1997 (BRASIL, 1997). Handling of food and money by the same person, and without hand washing, is a common practice among street vendors, which may increase the risk of food contamination (FORTUNA; FORTUNA, 2008).

The counts of total and thermotolerant coliforms in the unprocessed cooled fresh coconut water samples manually extracted by street vendors are shown in Table 2 .

All samples evaluated presented at least $210 \mathrm{MPN} \mathrm{mL}^{-1}$, and maximum count of $1,100 \mathrm{MPN} \mathrm{mL}^{-1}$ of total coliforms. Growth of thermotolerant coliforms was observed in $58.33 \%$ of the samples.

Presence of coliform bacteria in foods is an indicative of inappropriate hygienic-sanitary in the production, storage, or
Table 2. Counts of total and thermotolerant coliforms in unprocessed cooled fresh coconut water samples manually extracted by street vendors.

\begin{tabular}{|lcc|} 
Sample & $\begin{array}{c}\text { Total coliforms } \\
\text { MPN mL }\end{array}$ & $\begin{array}{c}\text { Thermotolerant coliforms } \\
\text { MPN mL }\end{array}$ \\
\hline 1 & 460 & 240 \\
\hline 2 & $>1,100$ & 150 \\
\hline 3 & 210 & 75 \\
\hline 4 & $>1,100$ & $<0.3$ \\
\hline 5 & $>1,100$ & $<0.3$ \\
\hline 6 & $>1,100$ & $<0.3$ \\
\hline 7 & $>1,100$ & 3.6 \\
\hline 8 & $>1,100$ & 3.0 \\
\hline 9 & $>1,100$ & 3.6 \\
\hline 10 & $>1,100$ & $<0.3$ \\
\hline 11 & $>1,100$ & 9.2 \\
\hline 12 & $>1,100$ & $<0.3$ \\
\hline
\end{tabular}

selling conditions of the product (JAY, 2005; FROEHLICH, 2015), and may be associated with inadequate food handling by street vendors (CINTRA et al., 2017). FORTUNA; FORTUNA (2008) also found high contamination by these microorganisms in $34.4 \%$ of the coconut water samples traded by street vendors in Teixeira de Freitas, Bahia, Brazil.

\section{CONCLUSION}

The coconut water evaluated showed high concentration of the studied microbial groups and, consequently, low microbiological quality. Moreover, lack of standardization of its physicochemical quality parameters was found. Thus, regular use of good hygienic practices to handle coconut water manually extracted, and a more intense inspection by the regulatory agencies are necessary to promote a physicochemical and microbiological standardization of the coconut water when it is manually extracted by street vendors and trade as an unprocessed, cooled, and fresh beverage, and consequently, minimize consumer's health risks.

\section{REFERENCES}

ALBUQUERQUE, T.L.D.; ARCANJO, M.R.; SOARES, M.V.; SÁ, T.N.; MARTINS, C.M.; MARTINS, S.C. Qualidade microbiológica da água de coco comercializada por ambulantes no centro de Fortaleza, CE. Higiene Alimentar, São Paulo, v.25, n. 194/195, p.30-34, 2011.
AMERICAN PUBLIC HEALTH ASSOCIATION (APHA); AMERICAN WATER WORKS ASSOCIATION (AWWA); WATER ENVIRONMENT FEDERATION (WEF). Standard Methods for the examination of water and wastewater. Washington, D.C.: APHA, 1998. 
ARAGÃO, W.M.; ISBERNER, I.V.; CRUZ, E.M.O. Água-de-coco. Aracaju: Embrapa, 2001. (Empraba Tabuleiros Costeiros, Série Documentos, 24).

AROUCHA, E.M.M.; SOUZA, M.S.; SOARES, K.M.P.; AROUCHA FILHO, J.C.; PAIVA, C.A. Análise físico-química e sensorial de água-de-coco em função de estádio de maturação das cultivares de coco anão verde e vermelho. Revista Agropecuária Científica no Semi-Árido, Paraíba, v.10, n.1, p.33-38, 2014.

BRASIL. Ministério da Saúde. Portaria MS n 326 de junho de 1997. Regulamento técnico sobre as condições higiênicosanitárias de boas práticas de fabricação para estabelecimentos produtores/industrializadores de alimentos. Diário Oficial da União, Brasília, 1997.

CARVALHO, J.M.; MAIA, G.A.; SOUSA, P.H.M.; MAIA JÚNIOR, G.A. Água de coco: Propriedades nutricionais, funcionais e processamento. Semina: Ciências Agrárias, Londrina, v.27, n.3, p.437-452, 2006.

CESÁRIO, M.C.P.; ANDRADE, M.V.V.; COELHO, A.A.; PEREIRA, S.M.F;; MARTINS, M.L.L.; HENRY, F.C. Avaliação físico química da áqua de coco. Higiene Alimentar, São Paulo, v.23, n. 176-177, p.39-42, 2009.

CINTRA, P.; GÓIS, E.M.; BRUNHARO, M.S.M.; MOREIRA, D.O.S. BoaS práticas de manipulação no comércio ambulante de alimentos em campus universitário da grande dourados, MS. Higiene Alimentar, São Paulo, v.31, n.266/267, p.27-30, 2017.

COELHO, A.A.; ANADRADE, M.V.V.; CESÁRIO, M.C.P.; PEREIRA, S.M.F.; MARTINS, M.L.L.; HENRY, F.C. Avaliação microbiológica da água de coco. Higiene Alimentar, São Paulo, v.24, n.180/181, p.68-72, 2010.

COSTA, L.M.C.; MAIA, G.A.; COSTA, J.M.C.D.; FIGUEIREDO, R.W.D.; SOUSA, P.H.M.D. Evaluation of coconut water obtained by different methods of conservation. Ciência e Agrotecnologia, Lavras, v.29, n.6, p.1239-1247, 2005.

FORSYTHE, S.J. Microbiologia da segurança dos alimentos. 2. ed. Porto Alegre: Artmed, 2013.607p.

FORTUNA, D.B.S.; FORTUNA, J.L. Avaliação da qualidade microbiológica e higiênico-sanitária da água de coco comercializada em carrinhos ambulantes nos logradouros do município de Teixeira de Freitas (BA). Revista Baiana de Saúde Pública, Salvador, v.32, n.2, p.203-217, 2008.

FREIRE, F.C.O.; VIEIRA, I.G.P.; GUEDES, M.I.F.; MENDES, F.N.P. Micotoxinas: importância na alimentação e na saúde humana e animal. Fortaleza: Embrapa Agroindústria Tropical, 2007. 48p.

FROEHLICH, A. Água de coco: aspectos nutricionais, microbiológicos e de conservação. Revista Saúde e Pesquisa, Maringá, v.8, n.1, p. $175-181,2015$.

HOFFMANN, F.L.; COELHO, A.R.; MANSOR, A.P.; TAKAHASHI, C.M.; VINTURIM, T.M. Qualidade microbiológica de amostras de água de coco vendidas por ambulantes na cidade de São José do Rio Preto - SP. Higiene alimentar, São Paulo, v.16, n.97, p.8792, 2002.

INSTITUTO ADOLFO LUTZ. Métodos químicos e físico-químicos para análises de alimentos. Brasília: Instituto Adolfo Lutz, 2008. 1.017p.

JAY, J.M. Microbiologia de alimentos. 6. ed. Porto Alegre: Artmed, 2005. $711 \mathrm{p}$.

LIMA, S.A.J.; MACHADO, A.V.; CAVALCANTI, M.T.; ARAÚJO D.R. Água de Coco comercializadas no Sertão do Ceará e Paraíba: Imprópria ao consumo. Revista Verde de Agroecologia e Desenvolvimento Sustentável, Pombal, v.9, n.4, p.21-26, 2014.

LIMA, S.A.J.; MACHADO, A.V.; CAVALCANTI, M.T.; ARAÚJO D.R. Caracterização físico-química de qualidade da água de coco anão verde industrializada. Revista Verde de Agroecologia e Desenvolvimento Sustentável, Pombal, v. 10, n. 1, p.35-42, 2015.

MICHELIN, A.F.; GARCIA, I.G.; MAURÍCIO, R.A.; BONHARO, T.M.; ROWE, R. Avaliação microbiológica e físico-química de água de coco verde vendida no comércio ambulante. Boletim do Instituto Adolfo Lutz, São Paulo, v.24, n.2, p.7-9, 2014.

SANTOS, J.E.F.; TEIXEIRA L.E.B.; MOREIRA I.S.; SOUSA F.C.; CASTRO, D.S. Avaliação microbiológica de água de coco comercializada por ambulante em Juazeiro do Norte - CE. Revista Verde de Agroecologia e Desenvolvimento Sustentável, Pombal, v.8, n.2, p.23-26, 2013.

SILVA, C.P.C.; OLIVEIRA, L.S.; SILVA, T.L.; ANDRADE FILHO, J.A.; REIS, I.A.O. Qualidade microbiológica de águas de coco (cocus nucifera) comercializadas no município de Aracaju, SE. Interfaces Científicas-Saúde e Ambiente, Aracaju, v.5, n.3, p.57-66, 2017.

SILVA, J.L.A.; DANTAS, F.A.V.; SILVA, F.C. Qualidade microbiológica de águas de coco comercializadas no município de Currais Novos/ RN. Holos, Natal, v.3, p. 34-41, 2009.

SILVA, N.; JUNQUEIRA, V.C.A.; SILVEIRA, N.F.A.; TANIWAKI, M.H.; SANTOS, R.F.S.; GOMES, R.A.R. Manual de Métodos de Análise Microbiológica de Alimentos. 3. ed. São Paulo: Varela, 2007.536p.

TAN, T.C.; CHENG, L.H.; BHAT, R.; RUSUL, G.; EASA, A.M. Composition, physicochemical properties and thermal inactivation kinetics of polyphenol oxidase and peroxidase from coconut (Cocos nucifera) water obtained from immature, mature and overly-mature coconut. Food Chemistry, v. 142, p.121-128, 2014.

VALVERDE, C.R.; BADARÓ, A.C.L. Qualidade microbiológica da água de coco (Cocus nucifera) comercializada por ambulantes na cidade de Ipatinga, Minas Gerais. Nutrir Gerais - Revista Digital de Nutrição, Ipatinga, v.3, n.5, p.489-504, 2009.

VERGARA, C.M.A.C. Gestão da qualidade na área de alimentos. Nutrivisa - Revista de Nutrição e Vigilância em Saúde, Fortaleza, v.2, n.3, p.99-100, 2016. 